\title{
Molecular modulation of osteocalcin and its relevance in diabetes (Review)
}

\author{
JOSÉ RAFAEL VILLAFÁN-BERNAL, SERGIO SÁNCHEZ-ENRÍQUEZ \\ and JOSÉ FRANCISCO MUÑOZ-VALLE
}

\begin{abstract}
Departamento de Biología Molecular y Genómica, Centro Universitario de Ciencias de la Salud, Universidad de Guadalajara, Colonia Independencia, CP 44340 Guadalajara, Jalisco, Mexico
\end{abstract}

Received January 21, 2011; Accepted March 16, 2011

DOI: $10.3892 /$ ijmm.2011.706

\begin{abstract}
Osteocalcin (OC) is encoded by the bone $\gamma$-carboxyglutamate (Gla) protein $(B G L A P)$ gene, and it is released by osteoblasts during osteogenesis. Its expression can be modulated by growth factors, hormones, cytokines and physical stimuli via signal transduction pathways, binding to the BGLAP gene promoter or interactions with nuclear transcription factors. It was recently demonstrated that uncarboxylated OC improves glucose tolerance and insulin sensitivity in mice by increasing the expression and secretion of insulin in $\beta$-cells and of adiponectin in adipocytes. Humans with type 2 diabetes have significantly lower serum levels of OC than healthy individuals and indeed, serum OC levels have been inversely correlated with fasting plasma glucose, fasting insulin and the homeostasis model assessment of insulin resistance (HOMA-IR) index. Moreover, several drugs have been shown to influence OC expression and its serum concentration. This review summarizes the molecular mechanisms involved in the modulation of OC expression, and discusses the potential relevance of $\mathrm{OC}$ in the pathogenesis and treatment of diabetes.
\end{abstract}

\section{Contents}

1. Introduction

2. BGLAP gene organization

Correspondence to: Dr José Francisco Muñoz-Valle, Sierra Mojada 950, Colonia Independencia, CP 44340 Guadalajara, Jalisco, Mexico

E-mail: biologiamolecular@hotmail.com

Abbreviations: OC, osteocalcin; cOC, carboxylated OC; ucOC, uncarboxylated OC; BGLAP, bone $\gamma$-carboxyglutamate protein; HOMA-IR, homeostasis model assessment of insulin resistance; $\mathrm{HbA}_{1 \mathrm{c}}$, glycated hemoglobin; FPG, fasting plasma glucose; VD, vitamin D; NMP, nuclear matrix proteins; RER, rough endoplasmic reticulum; PTH, parathyroid hormone

Key words: osteocalcin, metabolism, bone, insulin, diabetes
3. OC expression

4. Modulation of OC expression

5. Biological activities of OC

6. Evidence for the association of $\mathrm{OC}$ with markers of glycemic status in humans

7. Discussion

\section{Introduction}

Osteocalcin (OC) is the product of the bone $\gamma$-carboxyglutamate (Gla) protein $(B G L A P)$ gene, which is primarily expressed in osteoblasts and is regulated in response to physiological or pathological processes (1). Growth factors, hormones, cytokines, load and vibration have all been shown to modulate BGLAP gene expression through signal transduction pathways or through the interaction of nuclear transcription factors with the $B G L A P$ gene promoter (1-5). OC exists in two main forms, the carboxylated (cOC) and uncarboxylated (ucOC) forms. While cOC, that is considered a chemoattractant and an activator of cells with bone resorption properties $(6,7)$, has a high affinity for hydroxyapatite and mineral ions; ucOC improves glucose tolerance and insulin sensitivity in mice, protecting them against the development of diabetes (8). In humans, OC serum levels have been inversely correlated with glycated hemoglobin $\left(\mathrm{HbA}_{\mathrm{lc}}\right)$, fasting plasma glucose (FPG), fasting insulin and the homeostasis-model assessment insulin resistance (HOMA-IR) index; also, they are diminished in type 2 diabetes (9-11). Several drugs used in both clinical and non-clinical settings influence the serum levels of OC (12-15) and hence, might be of potential utility for the treatment of type 2 diabetes.

Here, we present an overview of the organization of the BGLAP gene and of the expression of OC; in addition, we describe how $\mathrm{OC}$ expression is modulated by various compounds. A synopsis of the biological activities of $\mathrm{OC}$ and its activity in humans is presented and finally, we discuss its potential relevance in diabetes pathogenesis and treatment.

\section{BGLAP gene organization}

The human BGLAP gene is a DNA sequence of $\sim 1700 \mathrm{bp}$ that is located at chromosome 1q25-q31 (GenBank Acc. no. X04143.1), and which shares a high degree of homology 




Figure 1. Schematic representation of the organization of the BGLAP gene. The BGLAP gene exhibits the same basic organizational features of most eukaryotic genes. A TATA box is located in the upstream region (at -42 to -39) of exon 1 and the OC box is a sequence of 24 nucleotides with a CAAT motif located in the proximal promoter region. There are three RUNX2 binding sites, named OSE2, a VDRE enhancer sequence located in the distal promoter region and several DNA sequences that are hormone response elements to glucocorticoids (GRE) and cAMP (cAMPRE). The BGLAP gene also has DNA sequences that are response elements for FGF (OCFRE) and TGFb (TGFbRE), four AP-1 binding sites and one DNA sequence for MSX2 binding. E1, Exon 1; E2, Exon 2; E3, Exon 3; E4, Exon 4.

with mammalian counterparts from the mouse, rat, monkey and pig $(1,16)$. The upstream sequences associated with the $B G L A P$ gene are approximately $700 \mathrm{bp}$ long from the 5'-end to the start site and they exhibit the same basic organizational features of most eukaryotic genes. These include: i) widely conserved DNA sequences; ii) DNA sequences responsive to hormones, cytokines and growth factors; iii) DNA sequences that bind to tissue specific-transcription factors; and iv) enhancer and silencer DNA sequences (5,17-23). Downstream from the start site, the gene contains four exons and three introns that are approximately 1,000 bp long (Fig. 1).

\section{OC expression}

The BGLAP gene encoding for OC is expressed efficiently in osteoblasts and odontoblasts, and more weakly in the ovaries, prostate, testes, skeletal muscle, thyroid and other tissues (24). In this section, we will review the expression of the $B G L A P$ gene, including its transcription, post-transcriptional processing, as well as the synthesis and release of OC.

BGLAP gene transcription and post-transcriptional processing. Transcription of the BGLAP gene is regulated temporarily, depending on the stage of osteogenesis and on the development of osteoblast precursors (25). While the BGLAP gene is switched off (inactive) during osteoblast proliferation, it is activated during differentiation (25). During this stage, transcriptional activation involves the basal transcription of the BGLAP gene as well as vitamin D (VD)-induced $B G L A P$ gene transcription, in which the rate of $B G L A P$ gene transcription increases 10- to 20 -fold $(25,26)$ (Fig. 2). Indeed, there is evidence that a sequence of events culminates in BGLAP gene transcription, including structural gene activation, and the binding of the appropriate transcription factors and DNA polymerase to the gene promoter.

Histone acetylation at the $\mathrm{OC}$ locus has been observed during bone-specific OC expression (27) and the interaction of histone deacetylase 3 with RUNX2 is thought to repress the OC promoter (28). Thus, structural activation of the $B G L A P$ gene appears to involve histone acetylation by histone acetyltransferases and simultaneous inactivation of histone deacetylases $(27,28)$. Once gene activation occurs, initiation of basal BGLAP gene transcription requires the binding of the specific elements to its cognate DNA sequences, including: i) basal transcription factors TFIID, TFIIA, TFIIB, TFIIF, TFIIE and TFIIH; ii) the osteoblast specific transcription factor RUNX2; iii) the OC box binding protein; and iv) RNA polymerase II (25,29-32).

Basal $B G L A P$ gene transcription can be enhanced by activators and co-activators. The most important activator is the VD-vitamin $\mathrm{D}$ receptor-retinoid $\mathrm{X}$ receptor complex (VD-VDR-RXR), which increases the rate of BGLAP transcription by binding to an enhancer sequence located at the distal gene promoter $(26,30,33)$. The binding of VD to VDR induces conformational changes in the receptor, facilitating its interaction with co-activators, such as NCoA-1/SRC-1, NCoA-2/GRIP/TIF2, CBP, p300 and DRIP (31). BGLAP gene transcription is repressed by transcription factors such as DLX3, MSX2, DLX5 and MEF, and by the glucocorticoidglucocorticoid receptor complex. This repression is achieved through interaction with RUNX2 $(17,34)$, binding to OC box (22) and by modulating the expression of other BGLAP regulators $(35,36)$, as well as by competition or interference with the binding of other transcription factors to the BGLAP gene promoter $(37,38)$. In addition, nuclear matrix proteins (NMP) participate in BGLAP gene transcription. Accordingly, NMP-1 and NPM-2 interact transiently with two binding elements for NMP located at the BGLAP gene promoter; hence. NMP could be important in concentrating and/or localizing transcription factors that mediate both basal and VD-induced BGLAP gene transcription $(39,40)$.

Six OC splice variants exist, such variants retain distinct combination of introns, although a dominant transcript containing all 3 introns has been detected by RT-PCR. These 6 variants encode proteins of 57 to 100 amino acids (aa) that are identical to pre-pro-OC in the N-terminal domain. However, only in bone-related tissue are all 3 OC introns efficiently spliced out (24).

$O C$ synthesis and release. Human OC synthesis occurs after the $B G L A P$ gene is transcribed and processed to OC mRNA, that is then translated in the rough endoplasmic reticulum (RER) to pre-pro-OC, a protein precursor of 98 aa residues $(1,16,41,42)$. Subsequently, pre-pro-OC undergoes proteolysis 
A

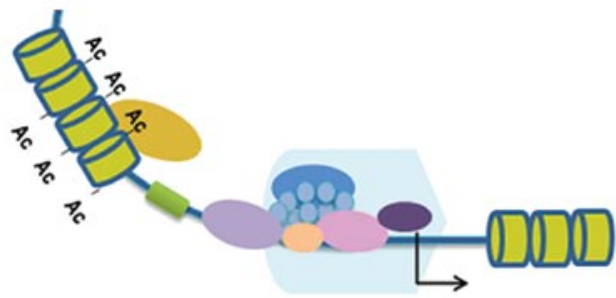

B



VD

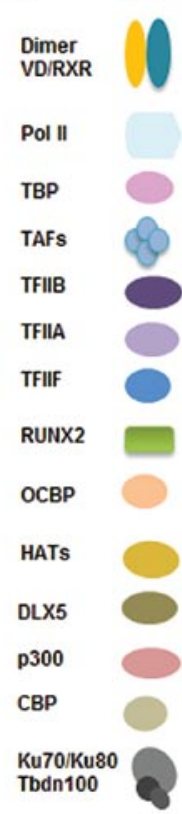

TIF-2

NCOA-1

NCOA-2

GRIP

SRC-1

ATF4

Figure 2. Basal and vitamin D (VD)-induced BGLAP gene transcription. (A) The basal BGLAP gene transcription that occurs when the TATA box, osteocalcin (OC) box and OSE2 are occupied by appropriate transcription factors. (B) The VD-induced BGLAP gene transcription due to the contribution of additional activators and co-activators.

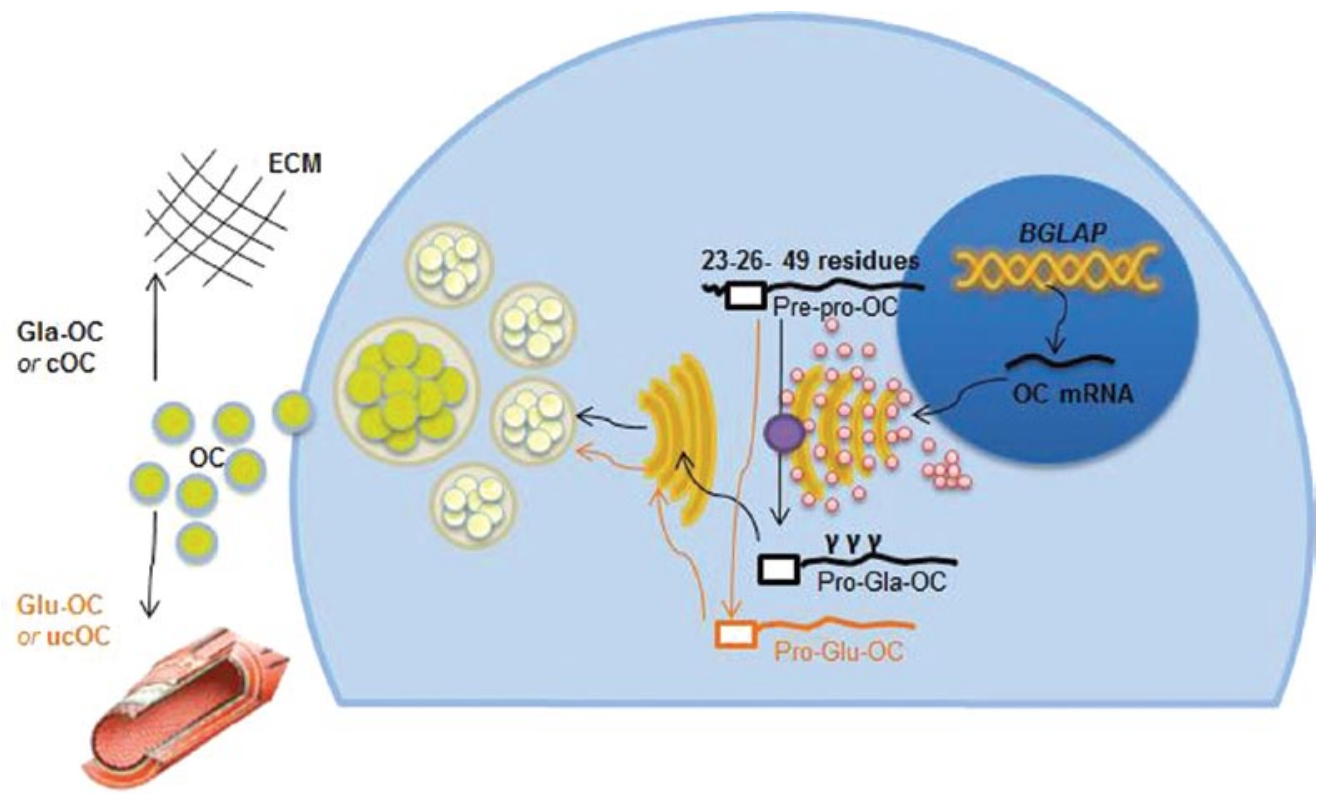

Figure 3. Osteocalcin (OC) synthesis and release. Human OC mRNA is translated in the rough endoplasmic reticultim (RER) as pre-pro-OC. pre-pro-OC is proteolytically cleaved to generate a pre-peptide and pro-OC. pro-OC is then directed to the RER membrane where GGCX carboxylates a proportion of pro-OC, at glutamic acid residues 17,21 and 24 , giving rise to pro-Gla-OC. The remaining pro-OC is not carboxylated and is referred to as pro-Glu-OC. Subsequently, pro-Gla-OC and pro-Glu-OC are cleaved to Gla-OC or cOC, and Glu-OC or ucOC. These two main forms are subsequently released, and a fraction of both reaches the bloodstream where they can be measured. Finally, the cOC is mainly deposited at the bone matrix where it interacts with calcium and hydroxyapatite, whereas ucOC acts on pancreatic and adipose tissues.

to form a pre-peptide (23 aa) and pro-OC (75 aa) $(1,16,41,42)$. The pro-peptide then directs pro-OC to the RER membrane where $\gamma$-glutamyl carboxylase (GGCX) carboxylates glutamic acid residues at the 17,21 and 24 positions, resulting in the formation of Gla-residues in a vitamin-K-dependent process $(43,44)$. However, this process only occurs in a proportion of newly synthesized pro-OC $(1,43)$. Pro-OC is ultimately subjected to a final proteolytic process that produces a propeptide (26 aa) and cOC or ucOC. Both forms are released from osteoblasts in a process which is calcium-dependent and relies on the activity of calcium and potassium channels (Fig. 3) $(45,46)$. 
Table I. Modulators of BGLAP gene expression and the level of their modulation.

\begin{tabular}{|c|c|c|c|c|}
\hline Molecule & Effect & Level of modulation & Experimental model & References \\
\hline \multicolumn{5}{|l|}{ Growth factors } \\
\hline IGF-1 & $\begin{array}{l}\uparrow \text { OC production; } \uparrow \text { OC mRNA, } \\
\text { stabilizes OC mRNA; } \uparrow \text { VD-induced } \\
\text { OC secretion and reversal of the } \\
\text { inhibitory effect of dexamethasone }\end{array}$ & $\begin{array}{l}\text { Transcriptional, } \\
\text { post-transcriptional }\end{array}$ & $\begin{array}{l}\text { IGF- } 1 \text { addition to mouse long bone } \\
\text { culture and to the human osteosarcoma } \\
\text { cell line MG- } 63\end{array}$ & 64,66 \\
\hline TGF- $\beta$ & $\downarrow$ OC production & Transcriptional & $\begin{array}{l}\text { TGF- } \beta \text { addition to mouse long bone } \\
\text { culture; rat osteosarcoma cell line } \\
\text { ROS } 17 / 2.8 \text {; human osteosarcoma cell } \\
\text { line MG- } 63\end{array}$ & $4,18,66$ \\
\hline bFGF & $\begin{array}{l}\uparrow \text { OC mRNA (independent of both } \\
\text { VD and retinoic acid activation } \\
\text { of the OC promoter) }\end{array}$ & Transcriptional & $\begin{array}{l}\text { bFGF transfection of rat osteosarcoma } \\
\text { cell line ROS } 17 / 2.8 \text {; bFGF injection } \\
\text { to ovariectomized rats in vivo }\end{array}$ & 23,67 \\
\hline BMP-2 & $\uparrow$ OC mRNA & Transcriptional & $\begin{array}{l}\text { BMP- } 2 \text { transfection of human periosteal } \\
\text { cells; addition of rBMP- } 2 \text { to fetal rat } \\
\text { calvarial osteoblasts KS } 483 \text { and to rat } \\
\text { primary osteoblastic cells; subcutaneous } \\
\text { injection of BMP-2 to mice }\end{array}$ & $68-70$ \\
\hline BMP-7 & $\begin{array}{l}\uparrow \text { OC mRNA; inhibits osteoblast } \\
\text { proliferation and induces } \\
\text { differentiation }\end{array}$ & Transcriptional & $\begin{array}{l}\text { BMP- } 7 \text { addition to the rat osteosarcoma } \\
\text { cell line ROS } 17 / 2.8\end{array}$ & 65 \\
\hline \multicolumn{5}{|l|}{ Hormones } \\
\hline $\begin{array}{l}\text { Parathyroid } \\
\text { hormone }\end{array}$ & $\begin{array}{l}\uparrow \text { OC mRNA through an increase in } \\
\text { cAMP and PKA which then activates } \\
\text { ATF4, with a weaker requirement } \\
\text { for the protein kinase } C \text { and the } \\
\text { MAPK/ERK pathways }\end{array}$ & Transcriptional & $\begin{array}{l}\text { PTH subcutaneous injection to C57BL/6J } \\
\text { mice; SaOS-2 osteosarcoma cell line } \\
\text { transfected with the OC promoter with } \\
\text { addition of PTH to the culture; MC- } 4 \\
\text { cells or osteoblasts transfected with the } \\
\text { OC promoter + PTH addition to the } \\
\text { culture }\end{array}$ & 74,75 \\
\hline Calcitonin & $\begin{array}{l}\uparrow \text { OC mRNA in vitro while } \\
\text { it has no effect in vivo }\end{array}$ & & $\begin{array}{l}\text { Addition of calcitonin to mouse } \\
\text { osteoblastic MC3T3-E1 cells; } \\
\text { calcitonin administration to rats }\end{array}$ & 76,78 \\
\hline Leptin & $\downarrow$ OC expression & Unknown & $\begin{array}{l}\text { Leptin and leptin receptor deficient mice } \\
\text { have increased bone formation and OC } \\
\text { expression }\end{array}$ & 79,80 \\
\hline Vitamin D & $\begin{array}{l}\uparrow B G L A P \text { gene transcription in vitro } \\
\text { and in vivo, thereby increasing OC } \\
\text { mRNA, OC synthesis and release } \\
\text { (has an opposite effect in the mouse) }\end{array}$ & Transcriptional & $\begin{array}{l}\text { VD addition to cultures (fetal rat } \\
\text { calvarial osteoblasts, ROS } 17 / 2.8 \text { ) } \\
\text { and supplementation to animals }\end{array}$ & $3,33,101$ \\
\hline Glucocorticoids & $\begin{array}{l}\text { Repression of } B G L A P \text { gene } \\
\text { expression by direct binding to the OC } \\
\text { promoter, thereby decreasing OC } \\
\text { mRNA in vivo and in vitro }\end{array}$ & Transcriptional & $\begin{array}{l}\text { Addition of dexamethasone to rat } \\
\text { osteosarcoma cells ROS } 17 / 2.8 \text {; } \\
\text { dexamethasone administration to rats }\end{array}$ & $\begin{array}{l}38,88 \\
95,101\end{array}$ \\
\hline Estrogens & $\begin{array}{l}\text { Repression of } B G L A P \\
\text { gene expression }\end{array}$ & Transcriptional & $\begin{array}{l}\text { Administration of estradiol dipropionate } \\
\text { to ovariectomized rats and measurement } \\
\text { of OC mRNA at the femur }\end{array}$ & 90,91 \\
\hline Progesterone & $\uparrow$ OC mRNA & Transcriptional & $\begin{array}{l}\text { Addition of progesterone } \\
\text { to fetal rat calvarial osteoblasts }\end{array}$ & $69,70,92$ \\
\hline
\end{tabular}


Table I. Continued.

\begin{tabular}{|c|c|c|c|c|}
\hline Molecule & Effect & Level of modulation & Experimental model & References \\
\hline Thyroid hormone & $\uparrow$ OC mRNA and protein levels & Transcriptional & $\begin{array}{l}\text { Addition of triiodothyronine (T3) } \\
\text { to MC3T3-E1 cells; systemic TSH } \\
\text { administration }\end{array}$ & 93 \\
\hline Retinoic acid & $\begin{array}{l}\text { Enhances the effect of VD on } \\
B G L A P \text { gene expression and } \\
\text { OC synthesis }\end{array}$ & Transcriptional & $\begin{array}{l}\text { Addition of retinoic acid to rat } \\
\text { osteosarcoma cells ROS } 17 / 2.8\end{array}$ & 89 \\
\hline \multicolumn{5}{|l|}{ Cytokines } \\
\hline IL-1 & $\downarrow B G L A P$ gene expression & Transcriptional & $\begin{array}{l}\text { Addition of IL-1 to human osteoblast- } \\
\text { like cultures and rat osteoblasts }\end{array}$ & 2 \\
\hline \multicolumn{5}{|l|}{ Physical stimuli } \\
\hline Load & $\uparrow B G L A P$ gene expression & Transcriptional & $\begin{array}{l}\text { Osteoblast differentiation induced by } \\
\text { mechanical forces; compressive forces } \\
\text { to rat calvarial osteoblasts }\end{array}$ & 47,48 \\
\hline Vibrations & $\uparrow B G L A P$ gene expression & Unknown & $\begin{array}{l}\text { Broad frequency vibration applied to } \\
\text { MC3T3-E1 cells }\end{array}$ & 50 \\
\hline \multicolumn{5}{|c|}{ Matrix-cell interactions } \\
\hline $\begin{array}{l}\text { Collagen- } \alpha_{2} \beta_{1} \\
\text { integrin } \\
\text { interaction }\end{array}$ & $\uparrow B G L A P$ gene expression & $\begin{array}{l}\text { Probably post- } \\
\text { translational or } \\
\text { via an accessory } \\
\text { factor }\end{array}$ & $\begin{array}{l}\text { Addition of anti- } \alpha_{2} \text { integrin antibody } \\
\text { to MC3T3-E1 cells blocks ascorbic } \\
\text { acid-dependent induction of the BGLAP } \\
\text { gene promoter }\end{array}$ & $58,59,61$ \\
\hline $\begin{array}{l}\text { Osteopontin- } \alpha v \\
\text { integrins }\end{array}$ & $\uparrow B G L A P$ gene expression & Unknown & $\begin{array}{l}\text { Addition of anti-osteopontin monoclonal } \\
\text { antibody inhibited OC expression in } \\
\text { MC3T3-E1 cells; addition of the } \\
\text { Arg-Gly-Asp peptidomimetic compound } \\
\text { or rOPN increased BGLAP gene } \\
\text { expression }\end{array}$ & 60 \\
\hline $\begin{array}{l}\text { Fibronectin- } \\
\alpha_{5} \beta_{1}, \alpha_{3} \beta_{1} \\
\text { and } \alpha_{8} \beta_{1} \\
\text { integrins }\end{array}$ & $\uparrow B G L A P$ gene expression & Unknown & $\begin{array}{l}\text { Addition of anti-integrin } \alpha_{5} \beta_{1}, \alpha_{3} \beta_{1} \text { and } \\
\alpha_{8} \beta_{1} \text { antibodies to fetal calvarial } \\
\text { osteoblasts decreases OC mRNA }\end{array}$ & 62 \\
\hline
\end{tabular}

$\uparrow$, increase; $\downarrow$, decrease. IGF-1, insulin-like growth factor 1 ; OC, osteocalcin; TGF- $\beta$, transforming growth factor- $\beta$; bFGF, basic fibroblast growth factor; BMP-2, bone morphogenetic protein-2; BMP-7, bone morphogenetic protein 2; PTH, parathyroid hormone; VD, vitamin D.

\section{Modulation of $\mathrm{OC}$ expression}

OC expression is regulated by growth factors, hormones, cytokines and physical stimuli, such as load and vibration (Fig. 4, Table I).

Physical stimuli modulate OC expression through Wnt/ $\beta$ catenin and matrix-cell interactions. Mechanical loading and vibrations have been shown to influence BGLAP gene expression. Simulated mechanical loading significantly increases OC expression both in vivo and in vitro $(47,48)$. Likewise, broad frequency vibration and dynamic stress (to simulate vibration) increase OC gene expression in cell culture $(49,50)$. These changes in OC expression in response to mechanical loading are mediated, at least in part, by activation of signal transduction pathways such as the Wnt/ $\beta$-catenin, MAPK and extracellular matrix-integrins-nuclear pathways $(20,51,52)$.

In the canonical Wnt $/ \beta$-catenin pathway, Wnt (ligand) binding to its receptor causes $\beta$-catenin stabilization and its accumulation in the cell cytosol. This $\beta$-catenin then translocates to the nucleus where it associates with the Tcf/LEF family of transcription factors, consequently regulating the expression of canonical Wnt target genes $(53,54)$ like Runx2 (55). Subsequently, RUNX2 (the product of Runx2) interacts with three DNA sequences in the BGLAP gene promoter to maintain its basal transcription $(26,30)$.

The bone extracellular matrix is composed of many proteins, including, OC, collagen, elastin, fibronectin, osteonectin, osteopontin and bone sialoprotein $(56,57)$. Such proteins 


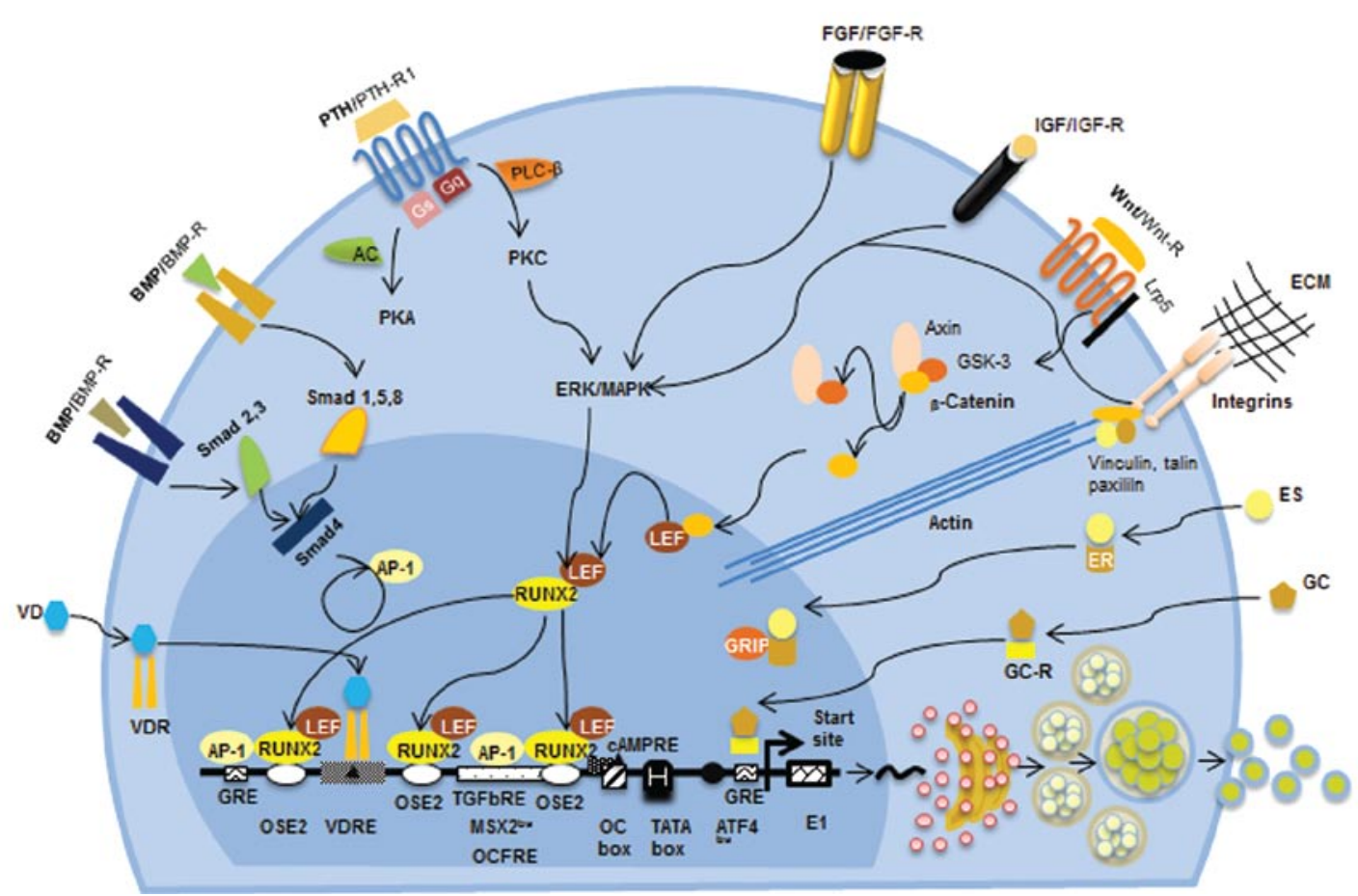

Figure 4. Main signal transduction pathways and protein/DNA interactions involved in modulating $B G L A P$ gene expression. Expression of the $B G L A P$ gene can be modulated by hormones, cytokines, matrix-cell interactions and growth factors via signal transduction pathways, binding to the $B G L A P$ gene promoter or interactions with nuclear transcription factors. The signal transduction pathways involve the PKC/PKA, Smad, ERK/MAPK and the Wnt/ $\beta$-catenin pathways. VD, vitamin D; VDR, VD receptor; GC, glucocorticoids; GR, glucocorticoid receptor; ES, estrogens; ER, estrogen receptor.

interact with integrins at the cell membrane acting as signals that can modify gene expression, including that of BGLAP, through the activation of cytoskeletal and intracellular proteins (actin, talin, vincullin, paxillin and MAPK) (20,58-60). In fact, OC expression can be modified by exposing cells in culture to blocking antibodies, proteins or peptides directed against specific integrin subunits or matrix proteins (59-62).

Growth factors modulate OC expression through BMP/TGF- $\beta$ signaling. Growth factors are essential for cell proliferation and organ growth, they are also capable of modulating OC expression (63). The transforming growth factor- $\beta$ (TGF- $\beta$ ) keeps the $B G L A P$ gene inactive during the proliferation stage of osteogenesis $(18,20)$. In contrast, the bone morphogenetic protein-7 (BMP-7) and the insulin-like growth factor (IGF-1) induce differentiation and $\mathrm{OC}$ expression during the mineralization stage of osteogenesis (64-66). Other growth factors, including the basic fibroblast growth factor (bFGF, also called FGF2), and BMP-2 $(67,68)$ can also modulate OC expression.

Growth factors mediate their effects on $\mathrm{OC}$ expression via the BMP/TGF- $\beta$ signaling pathway. Briefly, the binding of BMP to its membrane receptor in osteoblasts triggers a signaling cascade that activates Smad 1, 5 and 8 by phosphorylation. These members of the family form a complex with Smad 4 (also called C-Smad), which is subsequently translocated to the nucleus where it interacts with other transcription factors such as RUNX2 to modulate the activity of target genes including BGLAP (69-72). Conversely, TGF- $\beta$ binding to its membrane receptor results in activation of Smad 2 and Smad 3, which form a stable complex with Smad 4. This also translocates to the nucleus and interacts with transcription factors such as AP-1, VDR and p300/CBP, thereby positively or negatively modulating $B G L A P$ gene transcription $(20,31,73)$.

Peptide hormones modulate OC expression. Peptide hormones, including the parathyroid hormone (PTH), calcitonin and leptin, are involved in the modulation of BGLAP gene expression (74-78). PTH binds to its specific cell membrane receptor and activates several signal transduction pathways, including those mediated by protein kinase A (PKA), protein kinase $\mathrm{C}$ (PKC) and MAPK/ERK, resulting in increased BGLAP gene expression (see below). Calcitonin stimulates OC expression in a mouse osteoblastic cell line, whereas no such effect is observed in the appendicular and axial skeleton of the rat in vivo (76,78). Leptin modifies osteoblast function and downregulates OC expression through a hypothalamic relay that is mediated by the sympathetic nervous system $(79,80)$.

$P K A / P K C$ signaling modulates $O C$ expression. As indicated, PKA and PKC signaling is activated by PTH and binding of PTH to its G-protein-coupled receptor activates adenylyl cyclase and phospholipase $\mathrm{C}$, thereby increasing the intracellular levels of cAMP and/or $\mathrm{Ca}^{2+}$. Increased levels of these second messengers activate PKA and PKC, which in turn modulate OC expression $(74,81,82)$.

The MAPK-ERK signaling pathway is a common point of modulation in OC expression. The extracellular signal regulated kinase (ERK)-mitogen-activated protein kinase (MAPK) pathway represents an important link between the cell surface and the nucleus, and it influences proliferation and 
differentiation $(83,84)$. MAPK signaling up-regulates $B G L A P$ gene expression through RUNX2 activation, increasing OC mRNA levels (85). This signaling pathway is activated by cellmatrix interactions, cytokines, osteogenic growth factors, such as BMPs and bFGF, mechanical loading and hormones such as PTH (51). In each case, the common event in this cascade is the activation of MAPK, which in turn phosphorylates transcription factors and other proteins, such as RUNX2, ultimately modulating gene expression and other cell functions (86).

Lipid hormones and thyroid hormones modulate OC expression by interacting with the BGLAP gene promoter and transcription factors. Lipid-derived hormones are also implicated in the modulation of BGLAP gene expression. These include VD, glucocorticoids, estrogens, progesterone, triiodothyronine and retinoic acid. Lipid-derived hormones enter the cell to form complexes with specific cytoplasmic or nuclear receptors. These complexes then bind to specific DNA sequences of the BGLAP gene promoter or they interact with transcription factors (repressors or activators), which in turn modulate the rate of transcription $(3,33,37,69,87-97)$.

Drugs that up-regulate OC expression or serum levels. Several drugs are known to increase OC expression or serum levels. Glipizide and glybenclamide (blockers of ATP-dependent potassium channels) increase VD-induced OC secretion in cell cultures (45). This suggests that $\mathrm{OC}$ is released in osteoblasts by a mechanism similar to that which regulates insulin secretion in pancreatic $\beta$-cells (46). The bisphosphonates olpadronate (OPD) and IG-9402, increase OC release through the opening of voltage-dependent $\mathrm{Ca}^{2+}$ channels in the ROS 17/2.8 cell line, an effect abolished by $\mathrm{Ca}^{2+}$ channel blockers such as nifedipine and verapamil (15). The active form of VD, $1 \alpha-25(\mathrm{OH})_{2} \mathrm{D}_{3}(\mathrm{VD} 3)$, increases $\mathrm{OC}$ expression and release in osteoblasts. In fact, two VD metabolites, [25-OH-16,23Ediene- $\mathrm{D}_{3}(\mathrm{R})$ and $1 \alpha, 25-\mathrm{OH}(2)-16,23 \mathrm{E}-$ diene- $\left.\mathrm{D}_{3}(\mathrm{~A})\right]$, are 10 times more potent than VD3 in increasing OC mRNA expression and protein secretion (14). In addition TAK-788, which promotes osteoblast differentiation, increases OC release in rat bone marrow stromal cells (98). Genistein (a natural isoflavone phytoestrogen) significantly increases OC serum concentrations within 6-12 months of its administration to early postmenopausal women (99).

Drugs that down-regulate OC expression or serum levels. Other drugs demonstrably decrease $\mathrm{OC}$ expression or serum levels. The administration of glucocorticoids to humans decreases OC serum concentrations by decreasing OC expression and release $(12,37,100,101)$. Hydrochlorothiazide, a thiazide diuretic, decreases the serum concentration of OC by inhibition of BGLAP gene transcription via the $\mathrm{c}$-fos transcription factor (13). In addition, administration of low-doses of the antiepileptic drug levetiracetam to female rats over 90 days significantly reduces OC serum concentrations (102).

\section{Biological activities of $\mathrm{OC}$}

Since its discovery in chicken bone (103), OC has attracted considerable attention, leading to the elucidation of a number of biological roles for this molecule.
Roles of cOC in bone. Human cOC is a protein of 49 aa with carboxyglutamic acid (Gla) residues at positions 17, 21 and 24 (43). It is produced during the mineralization stage of osteogenesis and it possesses high affinity for hydroxyapatite and mineral ions like calcium (103). However, loss and gainof-function experiments have failed to identify a role for $\mathrm{OC}$ in extracellular matrix mineralization in vivo $(104,105)$. cOC is considered to be an activator and a chemoattractant molecule in cells with bone resorption properties $(6,7)$. Interestingly, OC-deficient mice exhibit increased bone formation (104), suggesting a central role for $\mathrm{COC}$ in the regulation of bone remodeling.

Endocrine actions of ucOC. The first data on the endocrine action of OC were reported in 2007. In their study, Lee et al demonstrated, both in cell culture and in mice, that ucOC in the pancreas increased $\beta$-cell proliferation, insulin expression and release, resulting in improved glucose tolerance (8). In addition, ucOC increased adiponectin expression and secretion in adipose tissue, which in turn enhanced insulin sensitivity (8). Furthermore, OC (-/-) mice show an increase in fat mass, adipocyte number and serum triglyceride levels, whereas $E s p(-/-)$ mice, which lack a protein responsible for down-regulation of OC expression and show high OC serum levels were protected against diet-induced obesity and diabetes (8). In 2008, the same group demonstrated that continuous infusion of recombinant $\mathrm{OC}(\mathrm{rOC})$ in wild-type mice i) improved glucose tolerance (at 0.03 and $0.3 \mathrm{ng} / \mathrm{h}$ ) and insulin sensitivity (at $30 \mathrm{ng} / \mathrm{h}$ ) and ii) increased insulin secretion (at 0.03 and $0.3 \mathrm{ng} / \mathrm{h}$ ). In addition, continuous infusion of rOC to mice fed a high-fat diet protected from weight gain and glucose intolerance and maintained triglyceride serum levels within the normal range (106).

\section{Evidence for the association of $\mathrm{OC}$ with markers of glycemic status in humans}

Well before the findings of Lee et al (8), lower serum concentrations of total $\mathrm{OC}$ were decribed in children with type 1 diabetes (107). Several studies showed lower total OC serum concentrations in patients with type 2 diabetes when compared to healthy subjects $(9,108-112)$. Actually, it was demonstrated that improved glycemic control in poorly controlled diabetic patients increased total OC serum concentrations and decreased $\mathrm{HbA}_{\mathrm{lc}}(108,113,114)$. Furthermore, the total OC levels were inversely correlated with $\mathrm{HbA}_{\mathrm{lc}}$ (115).

Up to this point, clinical studies had focused on the effects of diabetes on bone. However, the discovery of endocrine actions of ucOC in mice has focused research efforts on the possible role of $\mathrm{OC}$ in glycemic control in humans, prompting cross-sectional studies to identify the association of OC with type 2 diabetes and markers of the glycemic status. A recent study in Korean diabetic postmenopausal women found an inverse correlation between total OC and $\mathrm{FPG}, \mathrm{HbA}_{1 \mathrm{c}}$, fasting insulin and insulin resistance. Moreover, participants with total $\mathrm{OC}$ in the highest quartile had significantly lower FPG and $\mathrm{HbA}_{1 \mathrm{c}}$ (10). Furthermore, a study of Japanese men and postmenopausal women with type 2 diabetes also demonstrated an inverse correlation between total OC concentrations, FPG and $\mathrm{HbA}_{1 \mathrm{c}}$, and a positive correlation between 
total OC and total adiponectin, a hormone that enhances insulin sensitivity (11).

In healthy subjects, the association of $\mathrm{OC}$ with indicators of glycemic status and insulin resistance has also been studied. Among middle-aged males, elevated serum cOC and ucOC levels are associated with improved glucose tolerance and insulin sensitivity, as well as enhanced $\beta$-cell function (116). In healthy older men and women, elevated cOC concentrations are associated with lower insulin resistance (117). In men and women aged 65 and older (only 5\% with diabetes), total OC concentrations were inversely correlated with FPG, fasting insulin, HOMA-IR, high-sensitivity C-reactive protein, IL-6, body mass index and body fat (118). In addition, participants with total OC concentrations within the highest tertile had lower FPG concentrations than those in the lowest tertile (118). Furthermore, higher total OC concentration at onset was associated with a significant attenuation in the observed increase in FPG after a 3-year follow-up (118).

\section{Discussion}

OC has become a subject of increased interest in recent years based on its role in glycemic control in mice and the clinical evidence supporting a similar role in humans. However, many questions must be answered before its complete role in human metabolic control is fully understood. In addition, it remains to be determined if drugs that increase OC expression, or its release or accumulation in serum, could modulate glycemic control. Conversely, it must be determined whether those drugs that inhibit OC activity should be avoided in patients with type 2 diabetes.

It is well known that glucocorticoids increase glucose serum levels by enhancing gluconeogenesis and that they should thus be avoided in healthy and diabetic subjects (119). However, their negative effects on $\mathrm{OC}$ expression and serum concentrations may provide further reason for caution. Thiazide diuretics, such as hydrochlorotiazide can impair glucose metabolism and exacerbate new-onset diabetes (120). Their administration to both diabetic and non-diabetic subjects has negative effects on pancreatic $\beta$-cell and glucose-induced insulin secretion, as well as on OC expression and serum levels $(13,120)$. Thus it is possible that the impairment of glucose metabolism by thiazide diuretics may in part be due to impaired OC expression. Levetiracetam has not been associated with impaired glucose metabolism or diabetes; however, given that it significantly reduces OC serum concentrations in rats (102), its metabolic effect in humans should be determined. Glybenclamide and glipizide are effective in treating type 2 diabetes, and it is possible that their positive effects on glycemic control are in part due to an increase in OC serum concentrations, which could add therapeutic value to these drugs.

Given that bisphosphonates increase OC release in vitro (15), it may be interesting to test whether they have positive metabolic effects in postmenopausal type 2 diabetic women, in addition to their beneficial effects on bone mineral density. Conversely, it will be important to discount any deleterious effect of $\mathrm{Ca}^{2+}$ channel blockers on OC serum levels in vivo given their inhibition of OC release (15). Moreover, in light of the effects of VD and its metabolites, as well as TAK-788 and genistein, on $\mathrm{OC}$ expression and serum concentrations, it would be of interest to quantify their effects on glucose serum levels $(14,98,99)$. Some drugs targeting insulin signaling pathways are currently under development to treat type 2 diabetes (121-124). Thus, it may be valuable to test whether compounds targeting signaling pathways modulating OC expression and release could have a positive effect on glycemic control or the management of type 2 diabetes.

To date, neither the OC receptor nor the OC signaling pathways have been identified. The elucidation of these central components of OC activity on beta cells and adipocytes is vital, not only to fully understand the biological roles of OC but also to define additional therapeutic approaches to treat type 2 diabetes.

Dipeptidyl peptidase-IV (DPP-IV) is an enzyme that regulates the half-life of the incretin, glucagon-like peptide-1 (GLP-1). Inhibitors of DPP-IV are used to treat type 2 diabetes $(121,125)$. Given that OC, like GLP-1, increases $\beta$-cell proliferation and insulin synthesis and release, increasing the half-life of OC through the inhibition of modulatory proteases may potentially improve glycemic control in type 2 diabetes.

We previously found that patients with type 2 diabetes have a lower ucOC/cOC index than healthy subjects and that this value was negatively correlated with FPG and HOMA-IR levels. Subjects with an ucOC/cOC index within the highest quartile have lower FPG and HOMA-IR values than those in the lowest quartile (126). It remains to be determined whether any changes in $\gamma$-glutamyl carboxylase activity occurs in type 2 diabetes, or whether other factors might mediate the observed alterations in $\mathrm{ucOC} / \mathrm{cOC}$.

Lower OC levels have been widely reported in patients with type 2 diabetes $(9,108-112)$. However, it remains to be determined if low ucOC concentrations in type 2 diabetes represent a cause and/or a consequence of hyperglycemia. A deleterious effect of hyperglycemia on the bone has been suggested $(113,127,128)$, while a protective effect has been ascribed to high concentrations of OC in humans (118). As such, a causal effect of $\mathrm{OC}$ in type 2 diabetes cannot be discounted. In addition, it remains unclear which forms of $\mathrm{OC}$, ucOC, cOC or both, participate in the glycemic control in humans.

In conclusion, there is ample evidence supporting the participation of $\mathrm{OC}$ in the glycemic control and energy metabolism. Positive modulation of OC serum concentrations could be valuable for the prevention, delay and treatment of diabetes, while, drugs that have deleterious effects on OC serum levels and release should be used with caution.

\section{Acknowledgements}

This report was supported by the Consejo Estatal de Ciencia y Tecnología de Jalisco (PS-2008-718).

\section{References}

1. Hauschka PV, Lian JB, Cole DE and Gundberg CM: Osteocalcin and matrix Gla protein: vitamin K-dependent proteins in bone. Physiol Rev 69: 990-1047, 1989.

2. Beresford JN, Gallagher JA, Gowen M, et al: The effects of monocyte-conditioned medium and interleukin 1 on the synthesis of collagenous and non-collagenous proteins by mouse bone and human bone cells in vitro. Biochim Biophys Acta 801: $58-65,1984$. 
3. Lian JB, Coutts $\mathrm{M}$ and Canalis E: Studies of hormonal regulation of osteocalcin synthesis in cultured fetal rat calvariae. J Biol Chem 260: 8706-8710, 1985.

4. Noda M and Rodan GA: Type beta transforming growth factor regulates expression of genes encoding bone matrix proteins Connect Tissue Res 21: 71-75, 1989.

5. Gaur T: Canonical WNT signaling promotes osteogenesis by directly stimulating Runx2 gene expression. J Biol Chem 280 33132-33140, 2005.

6. Mundy GR and Poser JW: Chemotactic activity of the gammacarboxyglutamic acid containing protein in bone. Calcif Tissue Int 35: 164-168, 1983

7. Glowacki J and Lian JB: Impaired recruitment and differentiation of osteoclast progenitors by osteocalcin-deplete bone implants. Cell Differ 21: 247-254, 1987.

8. Lee NK, Sowa H, Hinoi E, et al: Endocrine regulation of energy metabolism by the skeleton. Cell 130: 456-469, 2007.

9. Pietschmann P, Schernthaner G and Woloszczuk W: Serum osteocalcin levels in diabetes mellitus: analysis of the type of diabetes and microvascular complications. Diabetologia 31: 892-895, 1988

10. Im JA, Yu BP, Jeon JY and Kim SH: Relationship between osteocalcin and glucose metabolism in postmenopausal women. Clin Chim Acta 396: 66-69, 2008.

11. Kanazawa I, Yamaguchi T, Yamamoto M, et al: Serum osteocalcin level is associated with glucose metabolism and atherosclerosis parameters in type 2 diabetes mellitus. J Clin Endocrinol Metab 94: 45-49, 2009.

12. Reid IR, Chapman GE, Fraser TR, et al: Low serum osteocalcin levels in glucocorticoid-treated asthmatics. J Clin Endocrinol Metab 62: 379-383, 1986

13. Lajeunesse D, Delalandre A and Guggino SE: Thiazide diuretics affect osteocalcin production in human osteoblasts at the transcription level without affecting vitamin D3 receptors. J Bone Miner Res 15: 894-901, 2000.

14. Kadiyala S, Nagaba S, Takeuchi K, et al: Metabolites and analogs of 1alpha,25-dihydroxyvitamin D(3): evaluation of actions in bone. Steroids 66: 347-355, 2001

15. Vazquez G, Santillan G, Boland R, Roldan E and Perez-Lloret A: Modulation of cytosolic calcium levels in osteoblast-like osteosarcoma cells by olpadronate and its amino-derivative IG-9402. Calcif Tissue Int 72: 215-221, 2003

16. Celeste AJ, Rosen V, Buecker JL, Kriz R, Wang EA and Wozney JM Isolation of the human gene for bone gla protein utilizing mouse and rat cDNA clones. EMBO J 5: 1885-1890, 1986.

17. Hoffmann HM, Catron KM, van Wijnen AJ, et al: Transcriptional control of the tissue-specific, developmentally regulated osteocalcin gene requires a binding motif for the Msx family of homeodomain proteins. Proc Natl Acad Sci USA 91: 12887-12891, 1994.

18. Banerjee C, Stein JL, van Wijnen AJ, Frenkel B, Lian JB and Stein GS: Transforming growth factor-beta 1 responsiveness of the rat osteocalcin gene is mediated by an activator protein-1 binding site. Endocrinology 137: 1991-2000, 1996.

19. Stein GS, Lian JB, van Wijnen AJ and Stein JL: The osteocalcin gene: a model for multiple parameters of skeletal-specific transcriptional control. Mol Biol Rep 24: 185-196, 1997

20. Franceschi RT: The developmental control of osteoblast-specific gene expression: role of specific transcription factors and the extracellular matrix environment. Crit Rev Oral Biol Med 10 40-57, 1999.

21. Aslam F, McCabe L, Frenkel B, et al: AP-1 and vitamin D receptor (VDR) signaling pathways converge at the rat osteocalcin VDR element: requirement for the internal activating protein-1 site for vitamin D-mediated trans-activation. Endocrinology 140: 63-70, 1999.

22. Willis DM, Loewy AP, Charlton-Kachigian N, Shao JS Ornitz DM and Towler DA: Regulation of osteocalcin gene expression by a novel $\mathrm{Ku}$ antigen transcription factor complex. J Biol Chem 277: 37280-37291, 2002.

23. Xiao G, Jiang D, Gopalakrishnan R and Franceschi RT: Fibroblast growth factor 2 induction of the osteocalcin gene requires MAPK activity and phosphorylation of the osteoblas transcription factor, Cbfa1/Runx2. J Biol Chem 277: 36181-36187, 2002.

24. Jung C, Ou YC, Yeung F, Frierson HF Jr and Kao C: Osteocalcin is incompletely spliced in non-osseous tissues. Gene 271: $143-150,2001$

25. Lian JB and Stein GS: Development of the osteoblast phenotype: molecular mechanisms mediating osteoblast growth and differentiation. Iowa Orthop J 15: 118-140, 1995.
26. Frenkel B, Montecino M, Green J, et al: Basal and vitamin D-responsive activity of the rat osteocalcin promoter in stably transfected osteosarcoma cells: requirement of upstream sequences for control by the proximal regulatory domain. Endocrinology 137: 1080-1088, 1996.

27. Shen J: Histone acetylation in vivo at the osteocalcin locus is functionally linked to vitamin D-dependent, bone tissue-specific transcription. J Biol Chem 277: 20284-20292, 2002.

28. Schroeder TM, Kahler RA, Li X and Westendorf JJ: Histone deacetylase 3 interacts with runx 2 to repress the osteocalcin promoter and regulate osteoblast differentiation. J Biol Chem 279: 41998-42007, 2004.

29. Blanco JC, Wang IM, Tsai SY, et al: Transcription factor TFIIB and the vitamin $\mathrm{D}$ receptor cooperatively activate ligand-dependent transcription. Proc Natl Acad Sci USA 92: 1535-1539, 1995.

30. Javed A, Gutierrez S, Montecino M, et al: Multiple Cbfa/AML sites in the rat osteocalcin promoter are required for basal and vitamin D-responsive transcription and contribute to chromatin organization. Mol Cell Biol 19: 7491-7500, 1999.

31. Sierra J, Villagra A, Paredes R, et al: Regulation of the bonespecific osteocalcin gene by $\mathrm{p} 300$ requires Runx $2 / \mathrm{Cbfa} 1$ and the vitamin D3 receptor but not p300 intrinsic histone acetyltransferase activity. Mol Cell Biol 23: 3339-3351, 2003.

32. Yu S, Jiang Y, Galson DL, et al: General transcription factor IIA-gamma increases osteoblast-specific osteocalcin gene expression via activating transcription factor 4 and runt-related transcription factor 2. J Biol Chem 283: 5542-5553, 2008

33. Paredes R, Arriagada G, Cruzat F, et al: Bone-specific transcription factor Runx2 interacts with the 1alpha,25-dihydroxyvitamin D3 receptor to up-regulate rat osteocalcin gene expression in osteoblastic cells. Mol Cell Biol 24: 8847-8861, 2004.

34. Hassan MQ, Javed A, Morasso MI, et al: Dlx3 transcriptional regulation of osteoblast differentiation: temporal recruitment of Msx2, Dlx3, and Dlx5 homeodomain proteins to chromatin of the osteocalcin gene. Mol Cell Biol 24: 9248-9261, 2004.

35. Shirakabe K, Terasawa K, Miyama K, Shibuya H and Nishida E: Regulation of the activity of the transcription factor Runx 2 by two homeobox proteins, Msx2 and Dlx5. Genes Cells 6: 851-856, 2001.

36. Newberry EP, Latifi T and Towler DA: Reciprocal regulation of osteocalcin transcription by the homeodomain proteins Msx2 and Dlx5. Biochemistry 37: 16360-16368, 1998.

37. Stromstedt PE, Poellinger L, Gustafsson JA and CarlstedtDuke J: The glucocorticoid receptor binds to a sequence overlapping the TATA box of the human osteocalcin promoter: a potential mechanism for negative regulation. Mol Cell Biol 11: 3379-3383, 1991.

38. Meyer T, Carlstedt-Duke J and Starr DB: A weak TATA box is a prerequisite for glucocorticoid-dependent repression of the osteocalcin gene. J Biol Chem 272: 30709-30714, 1997.

39. Stein GS, Lian JB, Dworetzky SI, et al: Regulation of transcription-factor activity during growth and differentiation: involvement of the nuclear matrix in concentration and localization of promoter binding proteins. J Cell Biochem 47: 300-305, 1991.

40. Bidwell JP, van Wijnen AJ, Fey EG, et al: Osteocalcin gene promoter-binding factors are tissue-specific nuclear matrix components. Proc Natl Acad Sci USA 90: 3162-3166, 1993.

41. Pan LC and Price PA: The propeptide of rat bone gammacarboxyglutamic acid protein shares homology with other vitamin K-dependent protein precursors. Proc Natl Acad Sci USA 82: 6109-6113, 1985.

42. Jorgensen MJ, Cantor AB, Furie BC, Brown CL, Shoemaker CB and Furie B: Recognition site directing vitamin K-dependent gamma-carboxylation resides on the propeptide of factor IX Cell 48: 185-191, 1987.

43. Poser JW, Esch FS, Ling NC and Price PA: Isolation and sequence of the vitamin K-dependent protein from human bone. Undercarboxylation of the first glutamic acid residue. J Biol Chem 255: 8685-8691, 1980.

44. Nishimoto SK, Chang CH, Gendler E, Stryker WF and Nimni ME: The effect of aging on bone formation in rats: biochemical and histological evidence for decreased bone formation capacity. Calcif Tissue Int 37: 617-624, 1985.

45. Moreau R, Aubin R, Lapointe JY and Lajeunesse D: Pharmacological and biochemical evidence for the regulation of osteocalcin secretion by potassium channels in human osteoblastlike MG-63 cells. J Bone Miner Res 12: 1984-1992, 1997.

46. Eliasson L, Abdulkader F, Braun M, Galvanovskis J, Hoppa MB and Rorsman P: Novel aspects of the molecular mechanisms controlling insulin secretion. J Physiol 586: 3313-3324, 2008. 
47. Pavlin D, Zadro R and Gluhak-Heinrich J: Temporal pattern of stimulation of osteoblast-associated genes during mechanicallyinduced osteogenesis in vivo: early responses of osteocalcin and type I collagen. Connect Tissue Res 42: 135-148, 2001.

48. Rath B, Nam J, Knobloch TJ, Lannutti JJ and Agarwal S: Compressive forces induce osteogenic gene expression in calvarial osteoblasts. J Biomech 41: 1095-1103, 2008.

49. Akhouayri O, Lafage-Proust MH, Rattner A, et al: Effects of static or dynamic mechanical stresses on osteoblast phenotype expression in three-dimensional contractile collagen gels. J Cell Biochem 76: 217-230, 1999.

50. Tanaka SM, Li J, Duncan RL, Yokota H, Burr DB and Turner CH: Effects of broad frequency vibration on cultured osteoblasts. J Biomech 36: 73-80, 2003.

51. Franceschi RT and Xiao G: Regulation of the osteoblast-specific transcription factor, Runx2: responsiveness to multiple signal transduction pathways. J Cell Biochem 88: 446-454, 2003.

52. Johnson ML and Kamel MA: The Wnt signaling pathway and bone metabolism. Curr Opin Rheumatol 19: 376-382, 2007.

53. Clevers H: Wnt/beta-catenin signaling in development and disease. Cell 127: 469-480, 2006.

54. Baron R and Rawadi G: Targeting the Wnt/beta-catenin pathway to regulate bone formation in the adult skeleton. Endocrinology 148: 2635-2643, 2007.

55. Case N, Ma M, Sen B, Xie Z, Gross TS and Rubin J: Beta-catenin levels influence rapid mechanical responses in osteoblasts. J Biol Chem 283: 29196-29205, 2008.

56. Manolagas SC: Birth and death of bone cells: basic regulatory mechanisms and implications for the pathogenesis and treatment of osteoporosis. Endocr Rev 21: 115-137, 2000.

57. Stupack DG and Cheresh DA: Get a ligand, get a life: integrins, signaling and cell survival. J Cell Sci 115: 3729-3738, 2002.

58. Takeuchi Y, Suzawa M, Kikuchi T, Nishida E, Fujita T and Matsumoto T: Differentiation and transforming growth factorbeta receptor down-regulation by collagen-alpha2beta1 integrin interaction is mediated by focal adhesion kinase and its downstream signals in murine osteoblastic cells. J Biol Chem 272: 29309-29316, 1997.

59. Xiao G, Wang D, Benson MD, Karsenty G and Franceschi RT: Role of the alpha2-integrin in osteoblast-specific gene expression and activation of the Osf 2 transcription factor. J Biol Chem 273: 32988-32994, 1998.

60. D'Alonzo RC, Kowalski AJ, Denhardt DT, Nickols GA and Partridge NC: Regulation of collagenase-3 and osteocalcin gene expression by collagen and osteopontin in differentiating MC3T3-E1 cells. J Biol Chem 277: 24788-24798, 2002.

61. Mizuno M and Kuboki Y: Osteoblast-related gene expression of bone marrow cells during the osteoblastic differentiation induced by type I collagen. J Biochem 129: 133-138, 2001.

62. Moursi AM, Globus RK and Damsky CH: Interactions between integrin receptors and fibronectin are required for calvarial osteoblast differentiation in vitro. J Cell Sci 110: 2187-2196, 1997.

63. Rizzino A: Understanding the roles of growth factors in carcinogenesis: modulation of autocrine growth control by differentiation. Int J Dev Biol 37: 61-65, 1993.

64. Pirskanen A, Jaaskelainen T and Maenpaa PH: Insulin-like growth factor-1 modulates steroid hormone effects on osteocalcin synthesis in human MG-63 osteosarcoma cells. Eur J Biochem 218: 883-891, 1993.

65. Maliakal JC, Asahina I, Hauschka PV and Sampath TK: Osteogenic protein-1 (BMP-7) inhibits cell proliferation and stimulates the expression of markers characteristic of osteoblast phenotype in rat osteosarcoma (17/2.8) cells. Growth Factors 11: 227-234, 1994.

66. Staal A, Geertsma-Kleinekoort WM, van Den Bemd GJ, et al: Regulation of osteocalcin production and bone resorption by 1,25-dihydroxyvitamin D3 in mouse long bones: interaction with the bone-derived growth factors TGF-beta and IGF-I. J Bone Miner Res 13: 36-43, 1998.

67. Schedlich LJ, Flanagan JL, Crofts LA, et al: Transcriptional activation of the human osteocalcin gene by basic fibroblast growth factor. J Bone Miner Res 9: 143-152, 1994.

68. Samee M, Kasugai S, Kondo H, Ohya K, Shimokawa H and Kuroda S: Bone morphogenetic protein-2 (BMP-2) and vascular endothelial growth factor (VEGF) transfection to human periosteal cells enhances osteoblast differentiation and bone formation. J Pharmacol Sci 108: 18-31, 2008.

69. Chen D, Harris MA, Rossini G, et al: Bone morphogenetic protein 2 (BMP-2) enhances BMP-3, BMP-4, and bone cell differentiation marker gene expression during the induction of mineralized bone matrix formation in cultures of fetal rat calvarial osteoblasts. Calcif Tissue Int 60: 283-290, 1997.
70. Chen D, Zhao M and Mundy GR: Bone morphogenetic proteins. Growth Factors 22: 233-241, 2004.

71. Takagi M, Kamiya N, Takahashi T, et al: Effects of bone morphogenetic protein-2 and transforming growth factor betal on gene expression of transcription factors, AJ18 and Runx 2 in cultured osteoblastic cells. J Mol Histol 35: 81-90, 2004.

72. Phimphilai M, Zhao Z, Boules H, Roca H and Franceschi RT: BMP signaling is required for RUNX2-dependent induction of the osteoblast phenotype. J Bone Miner Res 21: 637-646, 2006.

73. Sowa H: Menin is required for bone morphogenetic protein 2 - and transforming growth factor-regulated osteoblastic differentiation through interaction with Smads and Runx2. J Biol Chem 279: 40267-40275, 2004.

74. Yu XP and Chandrasekhar S: Parathyroid hormone (PTH 1-34) regulation of rat osteocalcin gene transcription. Endocrinology 138: 3085-3092, 1997.

75. Yu S, Franceschi RT, Luo M, et al: Parathyroid hormone increases activating transcription factor 4 expression and activity in osteoblasts: requirement for osteocalcin gene expression. Endocrinology 149: 1960-1968, 2008.

76. Kobayashi T, Sugimoto T, Saijoh K, Fukase M and Chihara K: Calcitonin directly acts on mouse osteoblastic MC3T3-E1 cells to stimulate mRNA expression of c-fos, insulin-like growth factor-1 and osteoblastic phenotypes (type 1 collagen and osteocalcin). Biochem Biophys Res Commun 199: 876-880, 1994.

77. Gordeladze JO, Drevon CA, Syversen U and Reseland JE: Leptin stimulates human osteoblastic cell proliferation, de novo collagen synthesis, and mineralization: Impact on differentiation markers, apoptosis, and osteoclastic signaling. J Cell Biochem 85: 825-836, 2002.

78. Jenis LG, Ongphiphadhanakul B, Braverman LE, et al: Responsiveness of gene expression markers of osteoblastic and osteoclastic activity to calcitonin in the appendicular and axial skeleton of the rat in vivo. Calcif Tissue Int 54: 511-515, 1994.

79. Ducy P, Amling M, Takeda S, et al: Leptin inhibits bone formation through a hypothalamic relay: a central control of bone mass. Cell 100: 197-207, 2000.

80. Hinoi E, Gao N, Jung DY, et al: The sympathetic tone mediates leptin's inhibition of insulin secretion by modulating osteocalcin bioactivity. J Cell Biol 183: 1235-1242, 2008.

81. Juppner H, Abou-Samra AB, Freeman M, et al: A G proteinlinked receptor for parathyroid hormone and parathyroid hormone-related peptide. Science 254: 1024-1026, 1991.

82. Boguslawski G, Hale LV, Yu XP, et al: Activation of osteocalcin transcription involves interaction of protein kinase A- and protein kinase C-dependent pathways. J Biol Chem 275: 999-1006, 2000.

83. Mordret G: MAP kinase kinase: a node connecting multiple pathways. Biol Cell 79: 193-207, 1993.

84. Pelech SL, Charest DL, Mordret GP, et al: Networking with mitogen-activated protein kinases. Mol Cell Biochem 127-128: $157-169,1993$.

85. Xiao G, Jiang D, Thomas P, et al: MAPK pathways activate and phosphorylate the osteoblast-specific transcription factor, Cbfa1. J Biol Chem 275: 4453-4459, 2000.

86. Johnson GL and Lapadat R: Mitogen-activated protein kinase pathways mediated by ERK, JNK, and p38 protein kinases. Science 298: 1911-1912, 2002.

87. Owen TA, Bortell R, Shalhoub V, et al: Postproliferative transcription of the rat osteocalcin gene is reflected by vitamin D-responsive developmental modifications in protein-DNA interactions at basal and enhancer promoter elements. Proc Natl Acad Sci USA 90: 1503-1507, 1993.

88. Leclerc N, Noh T, Khokhar A, Smith E and Frenkel B: Glucocorticoids inhibit osteocalcin transcription in osteoblasts by suppressing Egr2/Krox20-binding enhancer. Arthritis Rheum 52: $929-939,2005$.

89. Oliva A, Della Ragione F, Fratta M, Marrone G, Palumbo R and Zappia V: Effect of retinoic acid on osteocalcin gene expression in human osteoblasts. Biochem Biophys Res Commun 191: 908-914, 1993.

90. Kawano S, Kambe F, Ohmori S, Kanda K, Nagaya T and Seo H: Effect of estrogen and tail-suspension on expression of osteocalcin mRNA in femur of ovariectomized rats. Environ Med 44: 82-84, 2000.

91. Robinson JA, Harris SA, Riggs BL and Spelsberg TC: Estrogen regulation of human osteoblastic cell proliferation and differentiation. Endocrinology 138: 2919-2927, 1997.

92. Chen L and Foged NT: Induction of osteocalcin gene expression in vitro by progesterone. J Tongji Med Univ 17: 72-74, 1997. 
93. Varga F, Rumpler M, Luegmayr E, Fratzl-Zelman N, Glantschnig $\mathrm{H}$ and Klaushofer $\mathrm{K}$ : Triiodothyronine, a regulator of osteoblastic differentiation: depression of histone $\mathrm{H} 4$, attenuation of c-fos/c-jun, and induction of osteocalcin expression. Calcif Tissue Int 61: 404-411, 1997.

94. Schrader M, Bendik I, Becker-Andre M and Carlberg C: Interaction between retinoic acid and vitamin $\mathrm{D}$ signaling pathways. J Biol Chem 268: 17830-17836, 1993

95. Morrison NA, Shine J, Fragonas JC, Verkest V, McMenemy ML and Eisman JA: 1,25-dihydroxyvitamin D-responsive element and glucocorticoid repression in the osteocalcin gene. Science 246: 1158-1161, 1989.

96. Aslam F, Shalhoub V, van Wijnen AJ, et al: Contributions of distal and proximal promoter elements to glucocorticoid regulation of osteocalcin gene transcription. Mol Endocrinol 9: 679-690, 1995

97. Rickard DJ, Subramaniam M and Spelsberg TC: Molecular and cellular mechanisms of estrogen action on the skeleton. J Cell Biochem 75 (Suppl 32-33): S123-S132, 1999.

98. Notoya K, Nagai H, Oda T, et al: Enhancement of osteogenesis in vitro and in vivo by a novel osteoblast differentiation promoting compound, TAK-778. J Pharmacol Exp Ther 290: 1054-1064, 1999

99. Morabito N, Crisafulli A, Vergara C, et al: Effects of genistein and hormone-replacement therapy on bone loss in early postmenopausal women: a randomized double-blind placebocontrolled study. J Bone Miner Res 17: 1904-1912, 2002.

100. Lukert BP, Higgins JC and Stoskopf MM: Serum osteocalcin is increased in patients with hyperthyroidism and decreased in patients receiving glucocorticoids. J Clin Endocrinol Metab 62 1056-1058, 1986.

101. Viereck V, Siggelkow H, Tauber S, Raddatz D, Schutze N and Hufner M: Differential regulation of Cbfa1/Runx2 and osteocalcin gene expression by vitamin-D3, dexamethasone, and local growth factors in primary human osteoblasts. J Cell Biochem 86: 348-356, 2002.

102. Nissen-Meyer LS, Svalheim S, Tauboll E, et al: Levetiracetam, phenytoin, and valproate act differently on rat bone mass, structure, and metabolism. Epilepsia 48: 1850-1860, 2007.

103. Hauschka PV and Reid ML: Vitamin D dependence of a calcium-binding protein containing gamma-carboxyglutamic acid in chicken bone. J Biol Chem 253: 9063-9068, 1978.

104. Ducy P, Geoffroy V and Karsenty G: Study of osteoblast-specific expression of one mouse osteocalcin gene: characterization of the factor binding to OSE2. Connect Tissue Res 35: 7-14, 1996.

105. Murshed M: Extracellular matrix mineralization is regulated locally; different roles of two gla-containing proteins. J Cell Biol 165: 625-630, 2004

106. Ferron M, Hinoi E, Karsenty G and Ducy P: Osteocalcin differentially regulates cell and adipocyte gene expression and affects the development of metabolic diseases in wild-type mice. Proc Natl Acad Sci USA 105: 5266-5270, 2008.

107. Kruse $\mathrm{K}$ and Kracht U: Evaluation of serum osteocalcin as an index of altered bone metabolism. Eur J Pediatr 145: 27-33, 1986.

108. Rosato MT, Schneider SH and Shapses SA: Bone turnover and insulin-like growth factor I levels increase after improved glycemic control in noninsulin-dependent diabetes mellitus. Calcif Tissue Int 63: 107-111, 1998.

109. Akin O, Gol K, Akturk M and Erkaya S: Evaluation of bone turnover in postmenopausal patients with type 2 diabetes mellitus using biochemical markers and bone mineral density measurements. Gynecol Endocrinol 17: 19-29, 2003.

110. Achemlal L, Tellal S, Rkiouak F, et al: Bone metabolism in male patients with type 2 diabetes. Clin Rheumatol 24 493-496, 2005
111. Dobnig H, Piswanger-Solkner JC, Roth M, et al: Type 2 diabetes mellitus in nursing home patients: effects on bone turnover, bone mass, and fracture risk. J Clin Endocrinol Metab 91: 3355-3363, 2006.

112. Cutrim DM, Pereira FA, de Paula FJ and Foss MC: Lack of relationship between glycemic control and bone mineral density in type 2 diabetes mellitus. Braz J Med Biol Res 40: 221-227, 2007.

113. Nagasaka S, Murakami T, Uchikawa T, Ishikawa SE and Saito T: Effect of glycemic control on calcium and phosphorus handling and parathyroid hormone level in patients with non-insulindependent diabetes mellitus. Endocr J 42: 377-383, 1995.

114. Sayinalp S, Gedik O and Koray Z: Increasing serum osteocalcin after glycemic control in diabetic men. Calcif Tissue Int 57: 422-425, 1995

115. Guarneri MP, Weber G, Gallia P and Chiumello G: Effect of insulin treatment on osteocalcin levels in diabetic children and adolescents. J Endocrinol Invest 16: 505-509, 1993.

116. Hwang YC, Jeong IK, Ahn KJ and Chung HY: The uncarboxylated form of osteocalcin is associated with improved glucose tolerance and enhanced beta-cell function in middle-aged male subjects. Diabetes Metab Res Rev 25: 768-772, 2009.

117. Shea MK, Gundberg CM, Meigs JB, et al: Gamma-carboxylation of osteocalcin and insulin resistance in older men and women. Am J Clin Nutr 90: 1230-1235, 2009.

118. Pittas AG, Harris SS, Eliades M, Stark P and Dawson-Hughes B Association between serum osteocalcin and markers of metabolic phenotype. J Clin Endocrinol Metab 94: 827-832, 2009.

119. Clore JN and Thurby-Hay L: Glucocorticoid-induced hyperglycemia. Endocr Pract 15: 469-474, 2009.

120. Sowers JR, Raij L, Jialal I, et al: Angiotensin receptor blocker/ diuretic combination preserves insulin responses in obese hypertensives. J Hypertens 28: 1761-1769, 2010.

121. Moller DE: New drug targets for type 2 diabetes and the metabolic syndrome. Nature 414: 821-827, 2001.

122. Zhang ZY and Lee SY: PTP1B inhibitors as potential therapeutics in the treatment of type 2 diabetes and obesity. Expert Opin Investig Drugs 12: 223-233, 2003.

123. Hiromura M, Nakayama A, Adachi Y, Doi M and Sakurai H: Action mechanism of bis(allixinato)oxovanadium(IV) as a novel potent insulin-mimetic complex: regulation of GLUT4 translocation and FoxO1 transcription factor. J Biol Inorg Chem 12: 1275-1287, 2007.

124. Wang ZQ, Ribnicky D, Zhang XH, Raskin I, Yu Y and Cefalu WT: Bioactives of Artemisia dracunculus L enhance cellular insulin signaling in primary human skeletal muscle culture. Metabolism 57 (Suppl 1): S58-S64, 2008.

125. Virally M, Blickle JF, Girard J, Halimi S, Simon D and Guillausseau PJ: Type 2 diabetes mellitus: epidemiology, pathophysiology, unmet needs and therapeutical perspectives. Diabetes Metab 33: 231-244, 2007.

126. Villafán-Bernal JR, Munoz-Valle JF, Llamas-Covarrubias MA and Sanchez-Enriquez S: Relationship of uncarboxylated osteocalcin concentrations and ucOC/cOC index with the glycemic status in type 2 diabetes mellitus. Bone 46: S56, 2010.

127. Inaba M, Terada M, Koyama $\mathrm{H}$, et al: Influence of high glucose on 1,25-dihydroxyvitamin D3-induced effect on human osteoblast-like MG-63 cells. J Bone Miner Res 10: 1050-1056, 1995.

128. Okazaki R, Totsuka Y, Hamano K, et al: Metabolic improvement of poorly controlled noninsulin-dependent diabetes mellitus decreases bone turnover. J Clin Endocrinol Metab 82: 2915-2920, 1997. 